\title{
Política, Educação e a Realidade Educacional e Escolar
}

\section{César Apareciddo Nunes \\ Coordenador Geral do I POIETHOS \\ Editor do Dossiê I POIETHOS da Revista Filosofia e Educação \\ Gustavo Bolliger Simões \\ Secretário Geral do I POIETHOS \\ Editor do Dossiê I POIETHOS da Revista Filosofia e Educação}

presentamos o segundo volume da produção de textos e artigos
derivados do I Simpósio Nacional sobre Política, Ética e
Educação, ocorrido em junho de 2008 na Universidade Estadual de Campinas. A proposição e realização deste evento fora efetivada pelo Grupo de Estudos e Pesquisas em Filosofia e Educação PAIDEIA, mais precisamente sob a responsabilidade de uma de suas linhas de pesquisas, denominada Política, Ética e Educação. O volume I foi publicado no primeiro semestre desse ano (2011) e esse segundo volume versou sobre a dimensão mais propriamente vinculada à relação entre Ética e Educação. O volume atual pretende apresentar as reflexões e produções relacionadas à articulação entre Política e Educação.

A pesquisa em Educação, já com relativo acúmulo analítico e reflexivo na tradição recente do Brasil, volta-se para dimensões diversas de nossa realidade educacional e escolar, logrando cobrir todas suas facetas e desvendar suas contradições e potencialidades. Nessa conjunção de possibilidades as pesquisas e estudos de natureza política ocupam lugar destacado e singular proeminência. Desde a organização de um sistema nacional de educação, as esferas de financiamento e gestão da educação, as formas e matrizes de gestão da escola, suas articulações com o mundo do trabalho e suas relações com o modo de produção, as forças produtivas e suas relações, as concepções e tendências políticas matriciais, todas essas possibilidades de reflexões e embates se engendram nas linhas que articulam pesquisas de natureza política com a Educação. As propostas de produção de referenciais políticos e éticos de inspiração democrática e 
participativa, de encaminhamentos de práticas solidárias e sustentáveis igualmente reforçam o horizonte dos estudos políticos.

A Filosofia tem sido um campo fecundo de reflexões, críticas e propostas de estudos e projetos de natureza política. A política, desde as matrizes gregas, com Platão e Aristóteles, configura um campo de ação e de investigação do filósofo. A proposição de um simpósio que apresente essa temática integrada, Educação e Política, corresponde a um esforço de retomar as concepções clássicas da Filosofia e amiúde atualizar suas materialidades, efeitos, mediações e possibilidades. Os direitos sociais e as demandas de políticas publicas, derivadas de nossa histórica luta contra a tradição de exclusão que prevalecera em nossa identidade cultural e política parecem hoje estabelecer novos embates e utopias, na direção de assumir, nos inícios dessa segunda década do terceiro milênio, o papel ordenador de horizontes possíveis.

As Ciências da Educação buscam entender a dinâmica e dimensão dessa cisão e necessidade social; sua intenção matricial consiste, grosso modo, em buscar compreender os problemas e as contradições próprias do cenário estrutural da sociedade moderna, predominantemente urbana e industrial, marcada por diferentes interesses, conflitos e classes sociais no acesso à Educação e na apropriação de suas dimensionalidades. A questão social e política da Educação é um tema do século XIX, como tema científico próprio, antes presente na Filosofia, na Antropologia, na Demografia como parte da ciência econômica e seus derivados. A realidade da sociedade moderna exige uma ciência própria para a compreensão da identidade social desses problemas e suas causas, suas derivações e impactos. E essa dimensão não pode prescindir de sua organicidade política.

A tarefa de construir referenciais democráticos, participativos, coletivos, solidários, sustentáveis e emancipatórios não se restringe aos foros institucionais de atuação política, antes, devem estar presentes em todos os cenários e espaços da esfera pública e social. A universidade que tem compromissos orgânicos com a consolidação das bandeiras e demandas 
democráticas e solidarias deve guardar especial atenção ao debate político travado na junção das dimensões educacionais e os interesses coletivos.

Temos sentido possibilidades novas no horizonte social e político de nosso país. Como nos aponta Boaventura de Souza Santos, em seu mais recente trabalho, há possibilidades e determinações novas em curso na lógica do Estado e na organização da agenda política no Brasil recente. Este é o dilema de Boaventura, a nos instigar:

Enquanto no Brasil de hoje as despesas com políticas sociais (educação, saúde, protecção social) são considerados um investimento que propicia o crescimento, na Europa tais despesas são sentidas como um custo que impede o crescimento e como tal devem ser reduzidas ao mínimo. Perante este paradoxo, podemos nos perguntar se estamos perante dois mundos diferentes ou se a social-democracia desertou da Europa e emigrou para o Brasil. Quem está errado? Podem os dois estar certos? Mas, nesse caso, porque não escolher a solução que cria bem-estar para as grandes maiorias em vez da que cria mal-estar?

Tomamos como premissa a afirmação de que o pensamento é sempre determinado por forças sociais reais e projetos políticos materializados em diferentes propostas institucionais. A pesquisa em Educação, de natureza política, logrará entender essas tramas e desvendar esses fundamentos, potencialidades e determinações! Esperamos que todos possam encontrar aqui algumas dessas dimensões, a revitalizar a natureza mesma da Filosofia, vinculada à tarefa de decifrar a natureza da "polis" e determinada a formar o homem para compromissos e disposições para com sua realidade política.

O Grupo de Estudos em Filosofia e Educação PAIDEIA apresenta o conjunto de estudos, debates e comunicações apresentados no I POIETHOS, no diapasão da analítica e da interpretação política do fenômeno da Educação e suas articulações. Temos a convicção de que, longe de finalizar quaisquer dimensões ou tópicos da realidade política, aqui relatados, ao apresentá-los nesse espaço editorial somente logramos reencetar sua proposição sempre viva, ao franco diálogo e às novas disposições de pensar o mundo e sua transformação! 